\title{
Beneficial Impact and Molecular Mechanism of Bacillus coagulans on Piglets' Intestine
}

\author{
Tao Wu ${ }^{1,+}$, Yue Zhang ${ }^{1,+}$, Yang Lv ${ }^{1,+}{ }^{(1)}$, Peng Li ${ }^{1,+}{ }^{+}$Dan $\mathrm{Yi}^{1}{ }^{1}$, Lei Wang ${ }^{1}$, Di Zhao ${ }^{1}$, \\ Hongbo Chen ${ }^{1}$, Joshua Gong ${ }^{2}$ and Yongqing Hou ${ }^{1, *}$ \\ 1 Hubei Key Laboratory of Animal Nutrition and Feed Science, Wuhan Polytechnic University (WPHU), \\ Wuhan 430023, China; wutao@whpu.edu.cn (T.W.); m13971453158@163.com (Y.Z.); \\ yanglyu.yl@gmail.com (Y.L.); lipeng@whpu.edu.cn (P.L.); yidan810204@whpu.edu.cn (D.Y.); \\ wanglei@whpu.edu.cn (L.W.); zhaodi@whpu.edu.cn (D.Z.); chenhongbo@whpu.edu.cn (H.C.) \\ 2 Guelph Research and Development Centre, Agriculture and Agri-Food Canada, Guelph, ON N1G 5C9, \\ Canada; joshua.gong@agr.gc.ca \\ * Correspondence: houyq@whpu.edu.cn; Tel.: +86-027-8395-6175 \\ + These authors equally contributed to this work.
}

Received: 3 May 2018; Accepted: 11 July 2018; Published: 18 July 2018

\begin{abstract}
The aim of this research was to investigate the beneficial impact and molecular mechanism of $B$. coagulans on piglets' intestine. Twenty-four 21 days old weaned piglets were allotted to three treatments: Control group (basal diet), B6 group (basal diet $+2 \times 10^{6} \mathrm{CFU} / \mathrm{g}$ B. coagulans), and the B7 group (basal diet $+2 \times 10^{7} \mathrm{CFU} / \mathrm{g} B$. coagulans). The results showed that, compared with the control group, the B7 group had a reduced cholesterol content and gamma glutamyl transpeptidase (GGT) in plasma $(p<0.05)$; the B6 and B7 groups had a significantly decreased diarrhea rate and diamine oxidase (DAO) activity in plasma $(p<0.05)$, increased villus height in ileum and decreased crypt depth in the jejunum ( $p<0.05)$; increased activities of superoxide dismutase (SOD) and catalase (CAT), and decreased the content of malondialdehyde (MDA) and $\mathrm{H}_{2} \mathrm{O}_{2}$ in the intestine $(p<0.05)$. These data suggested that supplementing $B$. coagulans had beneficial impacts on promoting nutrients' metabolism, maintaining intestinal integrity, and alleviating oxidative stress and diarrhea. Further research of molecular mechanisms showed changing expression levels of related proteins and genes, suggesting that these could be involved in the regulation of the impact. The community composition of the gut microbiota was also found to be altered in several operational taxonomic units within the genus, Prevotella (order Bacteroidales), and the order, Clostridiales.
\end{abstract}

Keywords: Bacillus coagulans; intestinal function; gut microbiota; weaned piglet

\section{Introduction}

In the modern intensive pig production process, piglet feeding has become one of the most important aspects [1]. Weaning of piglets involves complex events, including environmental and dietary stresses, that interfere with gut development and adaptation [2], which is one of the most critical developmental stages of the digestive tract when food is changed from maternal milk to a solid diet [3]. This is a period of starvation associated with the absence of the dam, impairment of energy status, and thermoregulation, as shown by behavioral and biochemical changes [2-4]. After early weaning, piglets are prone to physiological and nutritional stress reactions and the immature development of their own organs, which results in a decrease in feed intake, slow weight growth, poor mental state, and severe diarrhea $[5,6]$. The long-term occurrence of these symptoms leads to a high morbidity and mortality of piglets [1]. This not only causes economical losses in pig production, but also contributes 
to public health risks from pathogenic bacteria-infected pork products, which has been perplexing the pig breeding industry for a long time [7], especially in the post-antibiotic era.

The intestine is not only the terminal organ for digestion and absorption of dietary nutrients, but is also crucial for preventing the entry of exogenous pathogens into the systemic circulation [8]. Thus, intestinal integrity is vital to survival, growth, and health of both animals and humans. Extensive studies have demonstrated that the early-weaning of piglets can result in gut mucosal injury and dysfunction $[9,10]$. Neonates are prone to various stresses, particularly after early-weaning, resulting in intestinal mucosal injury and absorptive dysfunction [8-11]. The consequences of this are the occurrence of diarrhea, reduced growth, and even death, leading to a considerable economic loss [11]. Therefore, it is urgent to find and explore high quality and safe antibiotic replacement products to improve the adverse reactions caused by weaning piglet syndrome, and to promote intestinal health.

The concept of probiotics, which are considered beneficial to the gastrointestinal tract as an alternative to antibiotics, has attracted increasing interest from animal nutritionists and livestock producers [12]. It is defined as a live microbial feed supplement that is beneficial to health [13]. The beneficial effects of probiotics in recent reports is mainly reflected in these aspects: (1) Produces a large number of active enzymes in the metabolism process and promotes the absorption of nutrients, thereby, improving the conversion efficiency of feed; (2) promotes the synthesis and metabolism of proteins and vitamins; (3) inhibits the reproduction of harmful bacteria in the intestinal tract, promotes the growth of beneficial bacteria, and maintains the dynamic balance of the gut microbiota; (4) regulates the immune function of the animal body to a certain extent; and (5) reduces the irritating gas in feces, thereby, purifying the air environment and reducing pollution [14-17].

As one kind of gram positive bacteria, Bacillus coagulans (B. coagulans) is a lactic acid producing bacterial species, which is catalase positive, spore forming, motile, and a facultative anaerobe [18]. Spores of B. coagulans have strong resistance, resurrection, and stability, can be activated in the acidic environment of the stomach, and begin germinating and proliferating in the intestine $[19,20]$. Spores can adapt to the low oxygen environment in the intestinal tract and reach the gastrointestinal tract smoothly, and then can play the effect of lactic acid bacteria in the gut [20]. Because of these characteristics, B. coagulans is often used in veterinary applications, especially as a probiotic in cattle, poultry, and shrimp, and many studies of its beneficial effects have been continuously reported [21].

Nevertheless, there is still limited evidence suggesting whether or how B. coagulans could affect molecular function, promote gut health, and maintain intestinal homeostasis in piglets. Therefore, the aim of this research was to investigate the beneficial impact and molecular mechanism of B. coagulans on piglets' intestines, by means of supplementing two levels of $B$. coagulans to the basal diet, and analyzing the molecular biology indexes. Moreover, this study might ultimately reveal the principle of how B. coagulans benefits the intestine via the maintenance of homeostasis and the regulation of biomolecular functions.

\section{Result and Discussion}

\subsection{Effects on Growth Performance and Nutrient Metabolism}

During the experimental period, the average daily gain (ADG), average daily feed intake (ADFI), and diarrhea rate were observed and calculated (Table 1). Although there was no significant difference in ADG and ADFI among the three groups, the data had a slight rise to some extent after supplementing B. coagulans. Moreover, the difference in diarrhea rate was remarkable. Compared with the control group, the B6 group had a significantly reduced diarrhea rate between day 0 and 10, and day 10 and 21, as well as day 0 and $21(p<0.05)$, and the B7 group had a significantly reduced diarrhea rate between day 0 and 10, as well as day 0 and $21(p<0.05)$. In addition, the diarrhea rate between day 10 and 21 in the B6 group was also exceedingly lower than that in the B7 group $(p<0.05)$.

Diarrhea is one of the most challenging problems in weaned piglet breeding. In the metabolic process, B. coagulans secretes the antibacterial peptide substance, coagulin, as well as lactic acid, 
which inhibits Listeria, Micrococcus, Leuconostoc, and Enterococcus, etc. [22]. There is evidence from animal research suggesting that $B$. coagulans is effective in both treating and preventing the recurrence of Clostridium difficile associated diarrhea [23]. In this study, we found the diarrhea rate was significantly reduced by the supplementation of $B$. coagulans, and $2 \times 10^{6} \mathrm{CFU} / \mathrm{g} B$. coagulans had a better effect in the second half of the trial.

Table 1. Effects of B. coagulans on growth performance of weaned piglets.

\begin{tabular}{cccc}
\hline Item & Control & B6 & B7 \\
\hline Day 0-10 & & & \\
ADG/g & $295.35 \pm 70.08$ & $334.07 \pm 51.97$ & $344.68 \pm 65.62$ \\
ADFI/g & $239.40 \pm 84.79$ & $263.20 \pm 62.74$ & $267.60 \pm 77.96$ \\
F/G & $1.28 \pm 0.21$ & $1.28 \pm 0.12$ & $1.29 \pm 0.04$ \\
Diarrhea rate/\% & $27.0^{\mathrm{b}}$ & $9.0^{\mathrm{a}}$ & $5.0^{\mathrm{a}}$ \\
\hline Day 10-21 & & \\
ADG/g & $592.02 \pm 122.77$ & $642.62 \pm 99.67$ & $635.90 \pm 96.64$ \\
ADFI/g & $403.27 \pm 119.01$ & $432.27 \pm 119.55$ & $409.82 \pm 166.78$ \\
F/G & $1.48 \pm 0.06$ & $1.53 \pm 0.22$ & $1.56 \pm 0.11$ \\
Diarrhea rate/\% & $11.8^{\mathrm{b}}$ & $0.9^{\mathrm{a}}$ & $5.5^{\mathrm{b}}$ \\
\hline Day 0-21 & & & \\
ADG/g & $450.72 \pm 96.11$ & $497.22 \pm 77.65$ & $495.68 \pm 72.39$ \\
ADFI/g & $325.24 \pm 97.15$ & $342.10 \pm 81.62$ & $354.95 \pm 81.05$ \\
F/G & $1.40 \pm 0.10$ & $1.46 \pm 0.06$ & $1.41 \pm 0.09$ \\
Diarrhea rate/\% & $19.5^{\mathrm{b}}$ & $5.2^{\mathrm{a}}$ & $5.7^{\mathrm{a}}$ \\
\hline & a,b Values within a row with different letters differ $(p<0.05)$. &
\end{tabular}

Plasma biochemical indicators were detected to reflect the metabolic function of piglets, with the results shown in Table 2. Compared with the control group, the B7 group had an obviously decreased total cholesterol (CHOL) and gamma glutamyl transpeptidase (GGT) and increased triglycerides (TG) in plasma $(p<0.05)$.

Table 2. Effects of B. coagulans on plasma biochemical indicators of weaned piglets.

\begin{tabular}{cccc}
\hline Item & Control & B6 & B7 \\
\hline TP (g/L) & $49.68 \pm 2.70$ & $48.86 \pm 4.17$ & $48.16 \pm 3.31$ \\
CHOL (mmol/L) & $1.77 \pm 0.29^{\mathrm{b}}$ & $1.71 \pm 0.19^{\mathrm{ab}}$ & $1.51 \pm 0.23^{\mathrm{a}}$ \\
TG (mmol/L) & $0.37 \pm 0.02^{\mathrm{a}}$ & $0.41 \pm 0.09^{\mathrm{ab}}$ & $0.46 \pm 0.08^{\mathrm{b}}$ \\
GLU (mmol/L) & $5.54 \pm 0.84$ & $5.48 \pm 0.16$ & $5.51 \pm 0.85$ \\
GGT (mmol/L) & $36.23 \pm 8.94^{\mathrm{b}}$ & $32.48 \pm 4.08^{\mathrm{ab}}$ & $28.67 \pm 5.25^{\mathrm{a}}$ \\
\hline & a,b Values within a row with different letters differ $(p<0.05)$.
\end{tabular}

Cholesterol levels in the blood are one of the routine blood testing indicators that is associated with many cardiovascular diseases [24]. Blood cholesterol is the main cause of atherosclerosis, and either high or low levels of cholesterol can lead to the damage of animal health [25]. GGT is mainly derived from the secretion of liver mitochondria, which is an essential enzyme for the metabolic process of amino acids and proteins [26]. GGT is also an indicator of oxidative stress that reflects the damage of oxygen free radicals to a variety of cells, and elevated GGT indicates damage to the liver and bile duct epithelium [27]. The results of this study showed that supplementing B. coagulans has the effect of lowering blood cholesterol, regulating the metabolism of amino acids and proteins, and decreasing stress reactions in the liver. Of note, although the triglycerides in plasma had a significant difference in this test, the content was still in the normal range.

In summary, the experiments of the effects on growth performance and nutrient metabolism indicated that, after weaning, supplementing $B$. coagulans could alleviate piglets' diarrhea, regulate the metabolism of nutrients, and mildly rise ADG and ADFI. For this, the analysis of the gut microbiota 
and expression levels of relative proteins and genes was carried out next to reveal this regulation mechanism further.

\subsection{Effects on Intestinal Integrity and Redox Status}

Diamine oxidase (DAO) activity is frequently used as a noninvasive biomarker of alterations in the function and structure of the intestinal mucosa [28]. Under certain conditions, cells in the intestinal mucosa experience necrosis, and slough off into the enteric entocoele, resulting in a decline of DAO levels in the intestinal mucosa and an increase of DAO levels in circulation [29]. In this research (Figure 1), both the B6 and B7 groups markedly reduced the activity of DAO in plasma $(p<0.05)$, indicating that supplementing B. coagulans alleviated the intestinal damage caused by weaning stress.

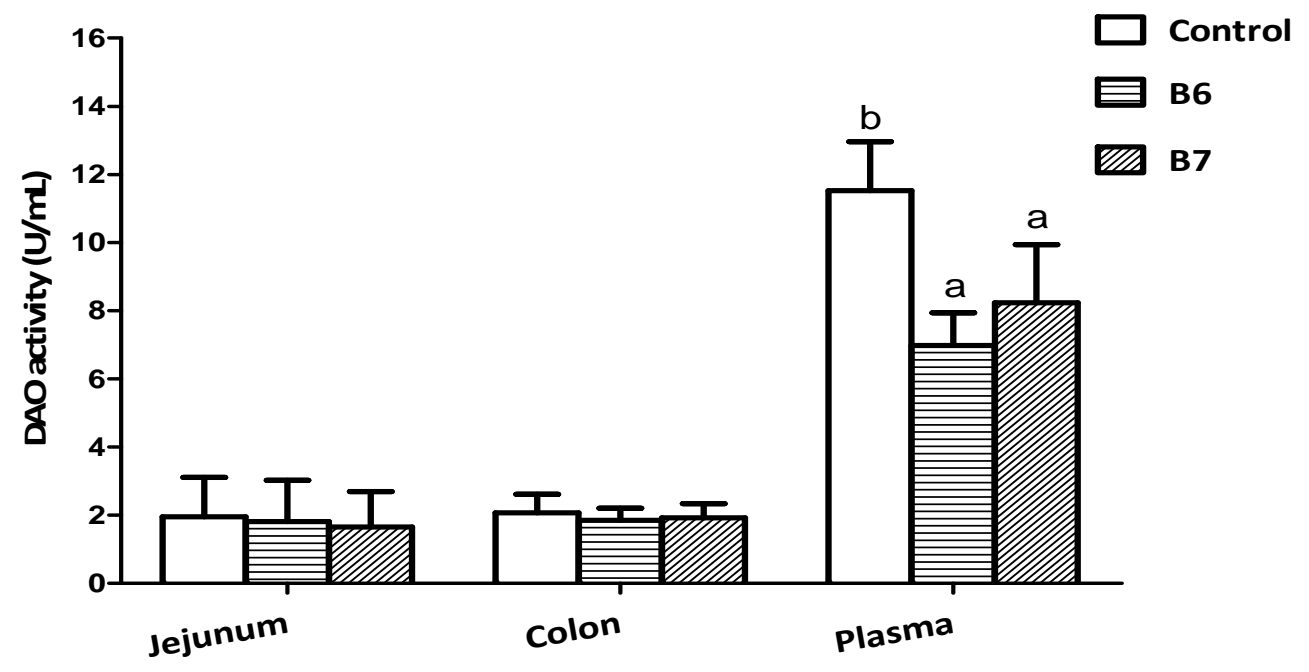

Figure 1. Effects of B. coagulans on diamine oxidase (DAO) activity in the jejunim, colon, and plasma. $\mathrm{a}, \mathrm{b}$ Values within a row with different letters differ $(p<0.05)$.

The data of the intestinal morphology was to reflect the intestinal mucosal integrity and injury, and are summarized in Table 3. Compared with control group, both the B6 and B7 groups significantly decreased the crypt depth and increased the ratio of villus height to crypt depth in the jejunum $(p<0.05)$, and significantly increased the villus height, as well as the ratio, in the ileum $(p<0.05)$. The height of the villus and the depth of the crypt directly reflect the function of the intestinal tract. The atrophy of the villus of the small intestine leads to a decrease in the number of mature epithelial cells, resulting in the nutrients not being fully absorbed by the intestine [30]. The depth of the crypt reflects the formation rate of villus epithelial cells, and the shallow crypt indicates the rate of cell maturation is increased and the secretory function is enhanced [31]. The data of this study showed that supplementing B. coagulans enhanced the repair of intestinal damage caused by weaning stress, thus, preserving the integrity of the intestinal mucosa.

Table 3. Effects of B. coagulans on the intestinal morphology of weaned piglets.

\begin{tabular}{|c|c|c|c|c|c|c|}
\hline \multirow{2}{*}{ Item } & \multicolumn{3}{|c|}{ Jejunum } & \multicolumn{3}{|c|}{ Ileum } \\
\hline & Control & B6 & B7 & Control & B6 & B7 \\
\hline villus height $(\mu \mathrm{m})$ & $318.7 \pm 35.0$ & $350.1 \pm 41.4$ & $336.6 \pm 41.2$ & $242.1 \pm 22.8^{a}$ & $273.3 \pm 19.8^{\mathrm{b}}$ & $285.2 \pm 30.7^{b}$ \\
\hline villus height/crypt depth & $1.49 \pm 0.11^{\mathrm{a}}$ & $2.08 \pm 0.17^{c}$ & $1.92 \pm 0.15^{\mathrm{b}}$ & $1.51 \pm 0.09^{\mathrm{a}}$ & $1.63 \pm 0.12^{b}$ & $1.65 \pm 0.08^{b}$ \\
\hline villous surface area $\left(\mathrm{cm}^{2}\right)$ & $29677 \pm 3031$ & $31738 \pm 3633$ & $29,540 \pm 4078$ & $27,520 \pm 932$ & $28,396 \pm 3715$ & $28,502 \pm 2870$ \\
\hline
\end{tabular}


The intestinal redox status was determined to reflect the oxidative stress and antioxidative function of piglets supplemented with B. coagulans (Table 4), including the activity of superoxide dismutase (SOD) and catalase (CAT), and the content of malondialdehyde (MDA) and hydrogen peroxide $\left(\mathrm{H}_{2} \mathrm{O}_{2}\right)$. Compared with the control group, the $\mathrm{B} 6$ group remarkably increased the activity of SOD in the duodenum and jejunum, as well as CAT in the colon, and decreased the content of MDA in the ileum and colon, as well as $\mathrm{H}_{2} \mathrm{O}_{2}$ in the jejunum and colon $(p<0.05)$; the $\mathrm{B} 7$ group markedly increased the activity of SOD in the jejunum, as well as CAT in the jejunum and colon, and decreased the content of MDA and $\mathrm{H}_{2} \mathrm{O}_{2}$ in the colon $(p<0.05)$. In addition, the difference of SOD, CAT, and $\mathrm{H}_{2} \mathrm{O}_{2}$ in the $\mathrm{B} 6$ group was larger than that in the $\mathrm{B} 7$ group.

Table 4. Effects of B. coagulans on the intestinal redox status of weaned piglets.

\begin{tabular}{|c|c|c|c|c|c|c|}
\hline Item & Control & B6 & B7 & Control & B6 & B7 \\
\hline & \multicolumn{3}{|c|}{ Duodenum } & \multicolumn{3}{|c|}{ Ileum } \\
\hline $\mathrm{SOD}(\mathrm{U} / \mathrm{mg})$ & $42.25 \pm 3.76^{\mathrm{a}}$ & $54.89 \pm 4.19^{b}$ & $45.48 \pm 3.30^{a}$ & $83.04 \pm 5.79$ & $78.95 \pm 3.00$ & $79.68 \pm 4.52$ \\
\hline CAT (U/mg) & $17.92 \pm 4.41$ & $16.61 \pm 2.73$ & $15.59 \pm 3.64$ & $9.54 \pm 3.08$ & $7.93 \pm 1.72$ & $7.92 \pm 1.40$ \\
\hline $\operatorname{MDA}(\mathrm{nmol} / \mathrm{mg})$ & $4.52 \pm 0.77$ & $5.82 \pm 1.77$ & $5.69 \pm 0.93$ & $6.00 \pm 2.40^{b}$ & $3.52 \pm 1.11^{\mathrm{a}}$ & $4.21 \pm 1.40^{\mathrm{ab}}$ \\
\hline \multirow[t]{2}{*}{$\mathrm{H}_{2} \mathrm{O}_{2}(\mathrm{nmol} / \mathrm{mg})$} & $5.06 \pm 1.10^{\mathrm{ab}}$ & $4.12 \pm 1.01^{\mathrm{a}}$ & $5.35 \pm 1.21^{b}$ & $8.34 \pm 1.80$ & $7.77 \pm 3.20$ & $7.49 \pm 1.82$ \\
\hline & \multicolumn{3}{|c|}{ Jejunum } & \multicolumn{3}{|c|}{ Colon } \\
\hline SOD (U/mg) & $81.55 \pm 10.51^{a}$ & $90.53 \pm 5.43^{b}$ & $94.21 \pm 6.36^{b}$ & $100.54 \pm 25.07$ & $95.62 \pm 4.92$ & $92.56 \pm 12.95$ \\
\hline CAT (U/mg) & $7.64 \pm 1.23^{\mathrm{a}}$ & $7.55 \pm 1.11^{\mathrm{a}}$ & $11.00 \pm 2.48^{b}$ & $6.56 \pm 1.15^{\mathrm{a}}$ & $10.58 \pm 2.40^{b}$ & $11.79 \pm 2.89^{b}$ \\
\hline MDA (nmol/mg) & $11.71 \pm 4.75$ & $9.61 \pm 4.82$ & $13.39 \pm 3.96$ & $3.66 \pm 1.74^{b}$ & $1.64 \pm 0.45^{\mathrm{a}}$ & $2.30 \pm 0.69^{a}$ \\
\hline $\mathrm{H}_{2} \mathrm{O}_{2}(\mathrm{nmol} / \mathrm{mg})$ & $30.75 \pm 10.31^{b}$ & $19.40 \pm 5.24^{\mathrm{a}}$ & $23.08 \pm 5.72^{a b}$ & $25.25 \pm 6.43^{b}$ & $19.61 \pm 5.00^{\mathrm{a}}$ & $16.80 \pm 3.04^{\mathrm{a}}$ \\
\hline
\end{tabular}

Oxidative stress reflects the unbalance between the systematic phenomenon of reactive oxygen species and the capacity of the biosystem to readily detoxify the reactive intermediaries or to renovate the resulting injury that frequently occurs after piglets' weaning [32,33], whereas, cells protect themselves from hydroxyl radicals and other oxygenants by antioxidant enzymes, including SOD and CAT $[33,34]$. MDA can induce noxious stress in cells and constitute homopolar protein adducts, known as advanced lipoxidation end-products (ALEs), which are usually utilized as a marker to evaluate the oxidant stress levels in a biosome [35]. $\mathrm{H}_{2} \mathrm{O}_{2}$ is the main product of oxidative stress in the body [36]. The results of the redox status showed that supplementing B. coagulans alleviated oxidative stress and enhanced the antioxidative capacity of the intestine. Furthermore, supplementing $2 \times 10^{6} \mathrm{CFU} / \mathrm{g}$ B. coagulans had a better effect in this test.

In summary, the experiments of the effects on the intestinal integrity and redox status indicated that, after weaning, supplementing $B$. coagulans could alleviate intestinal damage and oxidative stress, maintain intestinal integrity, and enhance antioxidative capacity. For this, the expression levels of relative proteins and genes was determined next to reveal this regulation and resistant mechanism further.

\subsection{Regulation of Protein Expression}

The expression levels of six proteins in the jejunum were tested to analyze the regulation of B. coagulans on the intestinal mucosal stress status and barrier function (Figure 2). Relative to the control group, the B6 group had significantly reduced protein expression levels of HSP70, Caspase-3, and Bax, and raised expression levels of Villin $(p<0.05)$; the B7 group had a significantly reduced protein expression level of Bax, and a raised expression level of Occludin $(p<0.05)$. 


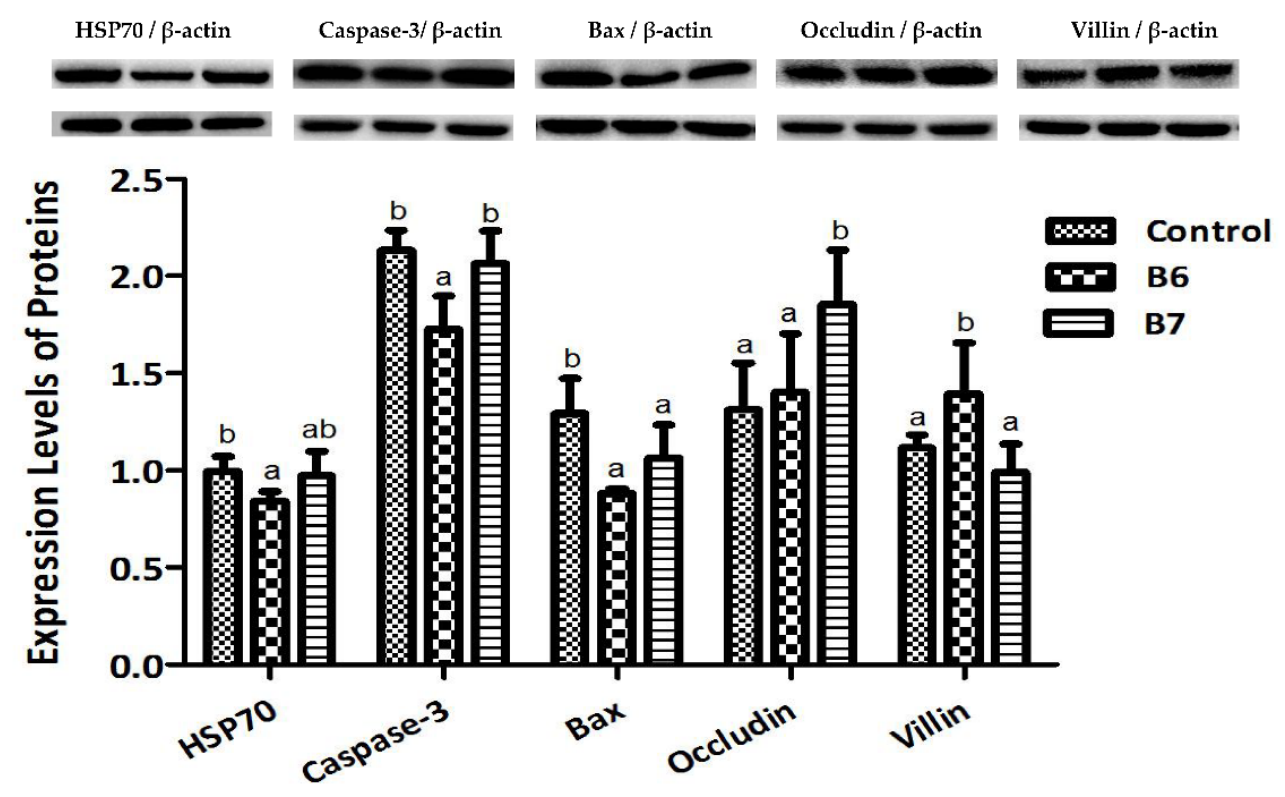

Figure 2. Effects of B. coagulans on the expression levels of proteins in the jejunum. ${ }^{a}, \mathrm{~b}$ Values within a row with different letters differ $(p<0.05)$.

In response to stress, HSP70 is expressed at elevated levels to promote refolding and prevent aggregation of partially-denatured proteins, thereby, protecting cells from injury [37]. Caspase- 3 is commonly activated by numerous "death" signals to cleave a variety of important cellular proteins that are responsible for the proteolytic cleavage of many key "death" proteins [38]. Bax resides in the outer mitochondrial membrane, and it promotes cell death directly through its putative function as a channel protein versus indirectly by inhibiting cellular regulators of the cell death proteases (caspases) [38,39]. In this research, we found the expression levels of these three proteins were remarkably decreased by $B$. coagulans, indicating that $B$. coagulans had a beneficial effect on regulating the related proteins to protect the intestine from stresses and injury, which is one of the mechanisms of resisting and alleviating weaning and oxidative stress.

Villin is one kind of actin binding protein and a marker of villus cell differentiation, which is conducive to prop up the microfilaments of the microvilli of the mucosal villus [40]. Occludin integrates such diverse processes as gene transcription, tumor suppression, and cell proliferation to modulate the intestinal mucosal structure and function [41]. After supplementing B. coagulans, the expression of these two proteins were regulated and obviously increased, indicating that B. coagulans had a beneficial effect on maintaining the intestinal barrier function and promoting the growth of villus, which might be exactly one of the key mechanisms of alleviating intestinal injury and diarrhea.

\subsection{Regulation of Gene Expression}

The expression levels of genes associated with intestinal immunity, inflammation, transportation, and absorption were tested to analyze the regulation of B. coagulans on the relative function (Table 5). Compared with the control group, the B6 group obviously increased the expression levels of IFN- $\alpha$, IFN- $\gamma, O A S 1, M X 2, I L-4, C C L-2, A Q P 3$, and $L P L$ in the ileum, and IFN- $\beta, S G L T-1$ and $b^{0,+} A T$ in the colon, while decreasing the expression levels of IL-4,CCL-2, and IFN- $\gamma$ in the colon $(p<0.05)$; the B7 group remarkably increased the expression levels of IFN- $\alpha, I F N-\beta, O A S 1, M X 2$, and $A Q P 3$ in the ileum and $M X 1, A Q P 3, S G L T-1, L P L, I N S R$, and $b^{0,+} A T$ in the colon, while decreasing the expression levels of CXCL-9 in the ileum and CXCL-9, IFN- $\gamma$, and IL-1 $\beta$ in the colon $(p<0.05)$. 
Table 5. Regulation of B. coagulans on the gene expression in the ileum and colon.

\begin{tabular}{|c|c|c|c|c|c|c|}
\hline \multirow{2}{*}{ Item } & \multicolumn{3}{|c|}{ Ileum } & \multicolumn{3}{|c|}{ Colon } \\
\hline & Control & B6 & B7 & Control & B6 & B7 \\
\hline$I F N-\alpha$ & $1.000 \pm 0.156^{\mathrm{a}}$ & $1.393 \pm 0.211^{b}$ & $2.124 \pm 0.383^{c}$ & $1.000 \pm 0.218$ & $1.041 \pm 0.220$ & $1.016 \pm 0.323$ \\
\hline$I F N-\beta$ & $1.000 \pm 0.239^{\mathrm{a}}$ & $1.247 \pm 0.219^{a b}$ & $1.337 \pm 0.313^{b}$ & $1.000 \pm 0.141^{\mathrm{a}}$ & $2.436 \pm 0.483^{b}$ & $0.905 \pm 0.205^{a}$ \\
\hline$I F N-\gamma$ & $1.000 \pm 0.167^{\mathrm{a}}$ & $1.276 \pm 0.202^{b}$ & $1.191 \pm 0.302^{\mathrm{ab}}$ & $1.000 \pm 0.223^{b}$ & $0.825 \pm 0.159^{a}$ & $0.682 \pm 0.078^{a}$ \\
\hline MX1 & $1.000 \pm 0.135$ & $1.000 \pm 0.230$ & $1.196 \pm 0.271$ & $1.000 \pm 0.172^{\mathrm{a}}$ & $0.937 \pm 0.159^{a}$ & $1.194 \pm 0.188^{b}$ \\
\hline MX2 & $1.000 \pm 0.144^{\mathrm{a}}$ & $2.015 \pm 0.264^{b}$ & $2.649 \pm 0.482^{c}$ & $1.000 \pm 0.239$ & $0.806 \pm 0.203$ & $0.976 \pm 0.236$ \\
\hline OAS1 & $1.000 \pm 0.148^{a}$ & $1.437 \pm 0.313^{b}$ & $1.467 \pm 0.354^{b}$ & $1.000 \pm 0.130$ & $1.088 \pm 0.212$ & $1.001 \pm 0.263$ \\
\hline$I L-1 \beta$ & $1.000 \pm 0.214$ & $1.022 \pm 0.125$ & $0.846 \pm 0.185$ & $1.000 \pm 0.257^{b}$ & $0.984 \pm 0.113^{b}$ & $0.708 \pm 0.130^{a}$ \\
\hline$I L-4$ & $1.000 \pm 0.265^{\mathrm{a}}$ & $1.540 \pm 0.300^{b}$ & $1.291 \pm 0.285^{\mathrm{ab}}$ & $1.000 \pm 0.168^{b}$ & $0.759 \pm 0.166^{a}$ & $0.870 \pm 0.229 a b$ \\
\hline CXCL-9 & $1.000 \pm 0.253^{b}$ & $0.868 \pm 0.119 \mathrm{ab}$ & $0.787 \pm 0.158^{a}$ & $1.000 \pm 0.204^{b}$ & $1.102 \pm 0.269^{b}$ & $0.729 \pm 0.186^{a}$ \\
\hline$C C L-2$ & $1.000 \pm 0.205^{\mathrm{a}}$ & $1.360 \pm 0.325^{b}$ & $1.143 \pm 0.275^{\mathrm{ab}}$ & $1.000 \pm 0.250^{b}$ & $0.646 \pm 0.096^{a}$ & $0.862 \pm 0.168^{b}$ \\
\hline$A Q P 3$ & $1.000 \pm 0.217^{\mathrm{a}}$ & $2.643 \pm 0.708^{b}$ & $2.382 \pm 0.602^{b}$ & $1.000 \pm 0.233^{\mathrm{a}}$ & $0.923 \pm 0.230^{\mathrm{a}}$ & $1.287 \pm 0.265^{b}$ \\
\hline SGLT-1 & $1.000 \pm 0.232 \mathrm{ab}$ & $0.843 \pm 0.132^{a}$ & $1.199 \pm 0.268^{b}$ & $1.000 \pm 0.203^{a}$ & $1.340 \pm 0.273^{b}$ & $1.358 \pm 0.223^{b}$ \\
\hline$L P L$ & $1.000 \pm 0.203^{a}$ & $1.307 \pm 0.276^{b}$ & $1.156 \pm 0.216^{\mathrm{ab}}$ & $1.000 \pm 0.195^{\mathrm{a}}$ & $0.857 \pm 0.127^{a}$ & $1.250 \pm 0.333^{b}$ \\
\hline$I N S R$ & $1.000 \pm 0.244$ & $1.104 \pm 0.275$ & $1.037 \pm 0.206$ & $1.000 \pm 0.203^{\mathrm{a}}$ & $1.016 \pm 0.186^{\mathrm{a}}$ & $1.390 \pm 0.311^{b}$ \\
\hline$b^{0,+} A T$ & $1.000 \pm 0.257$ & $1.017 \pm 0.219$ & $1.228 \pm 0.211$ & $1.000 \pm 0.215^{\mathrm{a}}$ & $1.678 \pm 0.390^{b}$ & $1.521 \pm 0.370^{b}$ \\
\hline
\end{tabular}

The cellular response to viral infection includes the induction of genes for the type I interferons, IFN- $\alpha$ and IFN $-\beta$, which are produced in most cell types and play a vital role in innate resistance to viral and bacterial infections [42]. IFN- $\alpha / \beta$ can induce the expression of genes encoding for antiviral proteins, particularly myxovirus (MX) and $2^{\prime}-5^{\prime}$ oligoadenylate synthetases (OAS) [43,44]. IFN $\gamma$, or type II interferon, is a cytokine that is critical for innate and adaptive immunity against viral, some bacterial, and protozoal infections [45]. In this research, we found there were marked alterations to the expression levels of these genes after supplementing B. coagulans, and the results indicated that B. coagulans regulated immune-related genes to improve immunity and inhibit pathogens in the intestine, which is one of the main mechanisms of lowering the diarrhea rate.

Oxidative stress is associated with early weaning, and it is suggested that oxidative stress may be one of the main causes of early weaning syndrome [46]. Oxidative stress has been implicated in the development of many chronic inflammatory disorders, such as enteritis, myocarditis, and thyroiditis [47]. Antioxidant defense systems may be impaired as a consequence of excessive oxidative stress, and inflammatory responses can be partially mediated by oxidative stress [48]. In this study, some inflammatory cytokines were remarkably changed after supplementing B. coagulans, including IFN- $\gamma, I L-1 \beta, I L-4, C X C L-9$, and $C C L-2$, implying that the beneficial impact of $B$. coagulans on alleviating weaning and oxidative stress was regulated by altering the expression levels of these inflammatory cytokines.

LPL (lipoprotein lipase) is expressed in heart, muscle, and adipose tissue, and it acts as a homodimer, obtaining the double functions of triglyceride hydrolase and ligand/bridging factor for receptor-mediated lipoprotein uptake [49]. INSR (insulin receptor) is a transmembrane receptor activated by insulin, including IGF-I and IGF-II. The binding of insulin or other ligands to this receptor activates the insulin signaling pathway, which regulates glucose uptake and release, as well as the synthesis and storage of carbohydrates, lipids, and proteins [50]. AQP3 is a selective aquaporin and is mainly distributed in intestinal epithelial cells, which can rapidly absorb water in the intestinal cavity into the blood and alter the endocrine environment of the intestinal cavity [51]. SGLT-1 (sodium glucose cotransporters-1) is a high affinity / low capacity transporter of glucose in the mammalian small intestine and kidneys, and is responsible for the entire glucose absorption in the small intestine [52]. $b^{0,+} A T\left(b^{0,+}\right.$ amino acid transporter) plays a role in the high-affinity and sodium-independent transport of cystine and neutral and dibasic amino acids, and appears to function in the reabsorption of cystine in the kidney tubule [53]. After supplementing B. coagulans, the expression of genes related to nutrients' absorption and transportation were significantly changed, implying that the beneficial impact of 
B. coagulans on promoting nutrients' metabolism was regulated by altering the expression levels of the identified genes.

\subsection{Regulation of Gut Microbiota}

The diversity analysis of the gut microbiota in the ileum, colon, and cecum are shown in Figure 3. There was a significant difference in the Shannon $\alpha$-diversity index between the control group $(6.43 \pm 0.27)$ and the B7 group $(5.92 \pm 0.45)$ in the colon $(p=0.039)$, but no difference among the three groups in the ileum and cecum. There was a significant difference in the $\beta$-diversity (weighted Unifrac) between the control and the B6 group ( $p=0.021)$, as well as between the B6 and B7 group $(p=0.021)$, in the ileum, between the control and the B7 group in the colon $(p=0.015)$, and between the control and the B6 group $(p=0.036)$, as well as between the control and the B7 group $(p=0.001)$ in the cecum.

A total of 1,313,016 reads were obtained from the ileum in the three groups, with 407,289 reads from the control group, 558,738 from the B6 group, and 346,989 from the B7 group. A total of 2,003,105 reads were obtained from the colon, 707,573 reads from the control group, 650,742 from the B6 group, and 651,835 from the B7 group. A total of 3,521,123 reads were obtained from the cecum, 902,813 reads from the control group, 1,213,060 from the B6 group, and 1,405,250 from the B7 group. The relative abundance of the OTUs (Operational Taxonomic Units) is summarized in Table 6. There were four OTUs with a significant difference in the ileum, 17 significant OTUs in the colon, and 15 significant OTUs in the cecum.

The mean relative abundances of the different predominant taxa at five levels in the community composition of each group are shown in Figure 4a-e. The dominant bacteria at the phylum level were Firmicutes and Proteobacteria in the ileum, and Bacteroidetes and Firmicutes in the colon and cecum. The dominant bacteria at the class level were Bacilli, Clostridia, and Gammaproteobacteria in the ileum, and Bacteroidia and Clostridia in the colon and cecum. The dominant bacteria at the order level were Bacteroidales, Enterobacteriales, Clostridiales, Lactobacillales, and Turicibacterales in the ileum, and Bacteroidales and Clostridiales in the colon and cecum. The dominant bacteria at the family level were Turicibacteraceae, Lactobacillaceae, o_Clostridiales. $\mathrm{f}$ (an unassigned family that belongs to the order Clostridiales), Clostridiaceae, and Enterobacteriaceae in the ileum, and Prevotellaceae, Ruminococcaceae, Veillonellaceae, Paraprevotellaceae, and Lachnospiraceae in the colon and cecum. The dominant bacteria at the genus level were Turicibacter, Clostridiales. f. g, Clostridiaceae. g, and Enterobacteriaceae. $\mathrm{g}$ in the ileum, and Lactobacillus and Prevotella in the colon and cecum.

Table 6. Relative abundance of the operational taxonomic units (OTUs).

\begin{tabular}{|c|c|c|c|c|c|c|}
\hline \multirow{2}{*}{ OTU } & \multirow{2}{*}{$p$ Value } & \multirow{2}{*}{$\begin{array}{c}\text { FDR } \\
p \text { Value }\end{array}$} & \multicolumn{3}{|c|}{ Relative Abundance } & \multirow{2}{*}{ Taxonomy } \\
\hline & & & C & B6 & B7 & \\
\hline \multicolumn{7}{|c|}{ Ileum } \\
\hline 4406684 & 0.003 & 0.845 & 6.000 & 5.125 & 0.143 & o_Bacteroidales; f_Prevotellaceae; g_Prevotella \\
\hline 299382 & 0.019 & 0.877 & 0.143 & 46.875 & 0.000 & o_Bacteroidales; f_Prevotellaceae; g_Prevotella \\
\hline OTU8146 & 0.020 & 0.877 & 0.714 & 0.000 & 1.857 & o_Clostridiales; f_Clostridiaceae; $\mathrm{g}$ \\
\hline 289257 & 0.038 & 0.877 & 2.857 & 13.875 & 1.571 & o_Bacteroidales; f_Prevotellaceae; g_Prevotella; \\
\hline \multicolumn{7}{|c|}{ Colon } \\
\hline 355450 & 0.012 & 0.943 & 22.250 & 14.000 & 2.000 & o_Clostridiales; $\mathrm{f}$ _Ruminococcaceae; $\mathrm{g}$ \\
\hline OTU128 & 0.013 & 0.943 & 0.000 & 48.500 & 4.250 & o_Bacteroidales; f_Prevotellaceae; g_Prevotella \\
\hline 613933 & 0.015 & 0.943 & 3.500 & 7.375 & 1.375 & o_Clostridiales; $\mathrm{f} \_\mathrm{g}_{-}$ \\
\hline 187350 & 0.017 & 0.943 & 2.375 & 0.125 & 3.125 & o_Clostridiales; $\mathrm{f}_{-} ; \mathrm{g}$ \\
\hline 325236 & 0.021 & 0.943 & 0.375 & 2.625 & 5.875 & o_Clostridiales; $\mathrm{f} ; \mathrm{g}$ \\
\hline 300859 & 0.022 & 0.943 & 61.125 & 31.625 & 30.875 & o_Bacteroidales; f_Prevotellaceae; g_Prevotella \\
\hline 36705 & 0.025 & 0.943 & 2.625 & 1.625 & 1.250 & o_Clostridiales; $\mathrm{f}$ _Clostridiaceae; $\mathrm{g}$ _Clostridium \\
\hline 4392188 & 0.026 & 0.943 & 7.375 & 1.375 & 1.875 & o_Clostridiales; $\mathrm{f} \_L a c h n o s p i r a c e a e ; \mathrm{g}_{-}$ \\
\hline OTU16964 & 0.031 & 0.943 & 0.500 & 2.875 & 0.000 & o_Clostridiales; $\mathrm{f}$ _Veillonellaceae; $\mathrm{g}$ _Acidaminococcus \\
\hline 301253 & 0.032 & 0.943 & 2.250 & 1.250 & 0.000 & o_Bacteroidales; f_Prevotellaceae; g_Prevotella \\
\hline 174019 & 0.033 & 0.943 & 1.125 & 10.625 & 1.250 & o_Clostridiales; f_Lachnospiraceae; g_Coprococcus \\
\hline
\end{tabular}


Table 6. Cont.

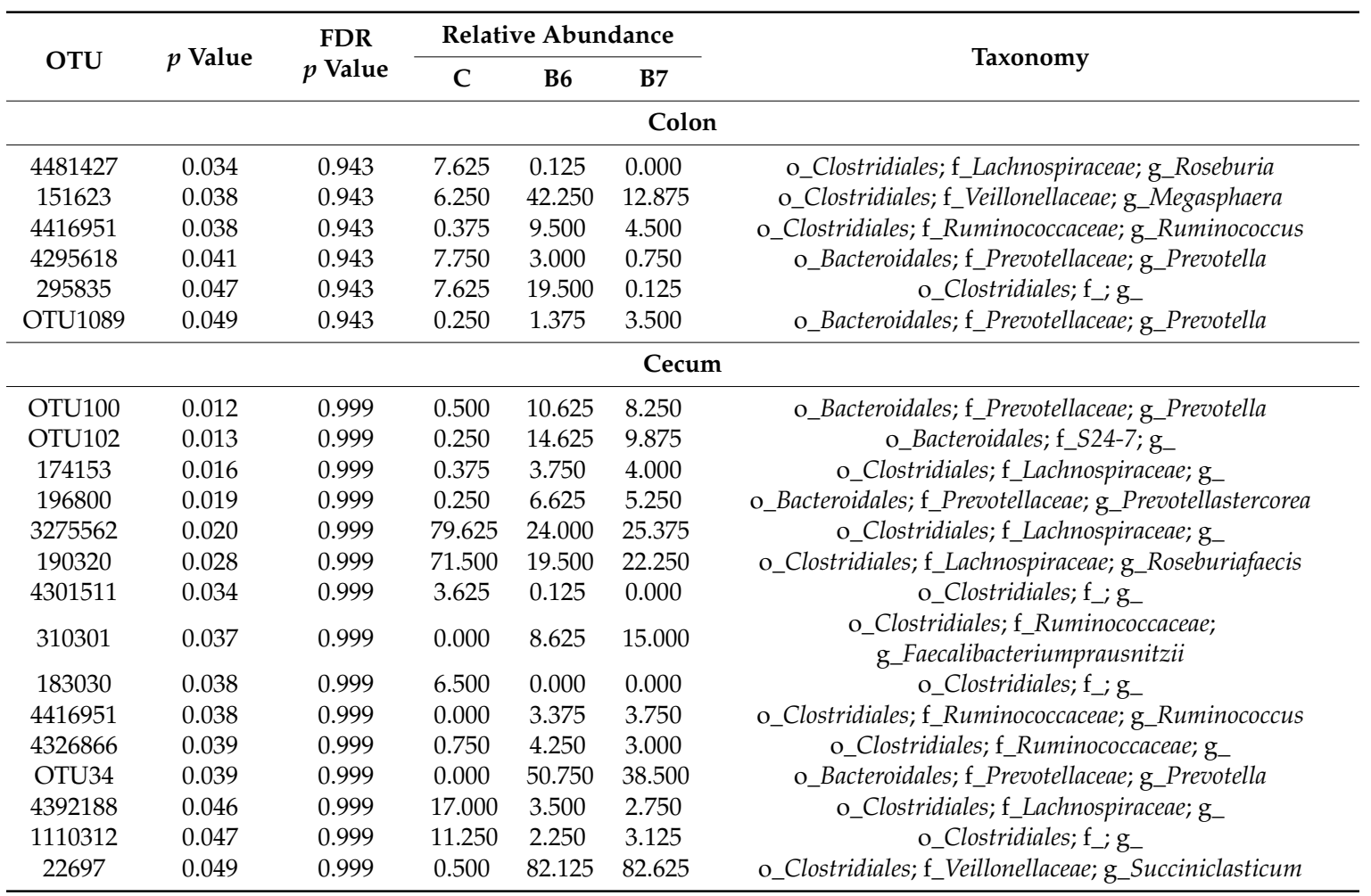
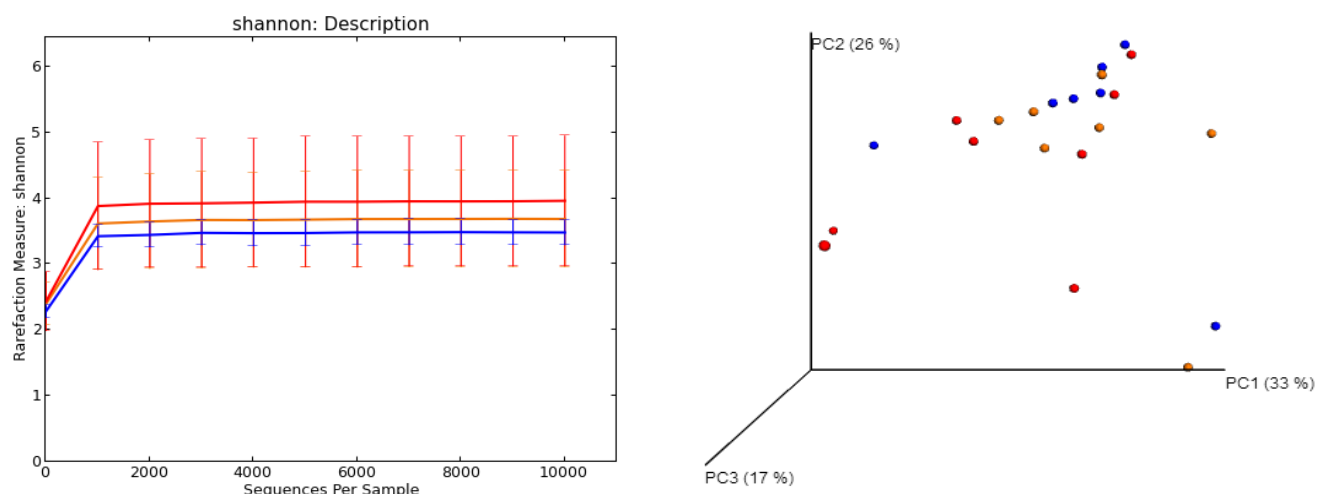

Ileum
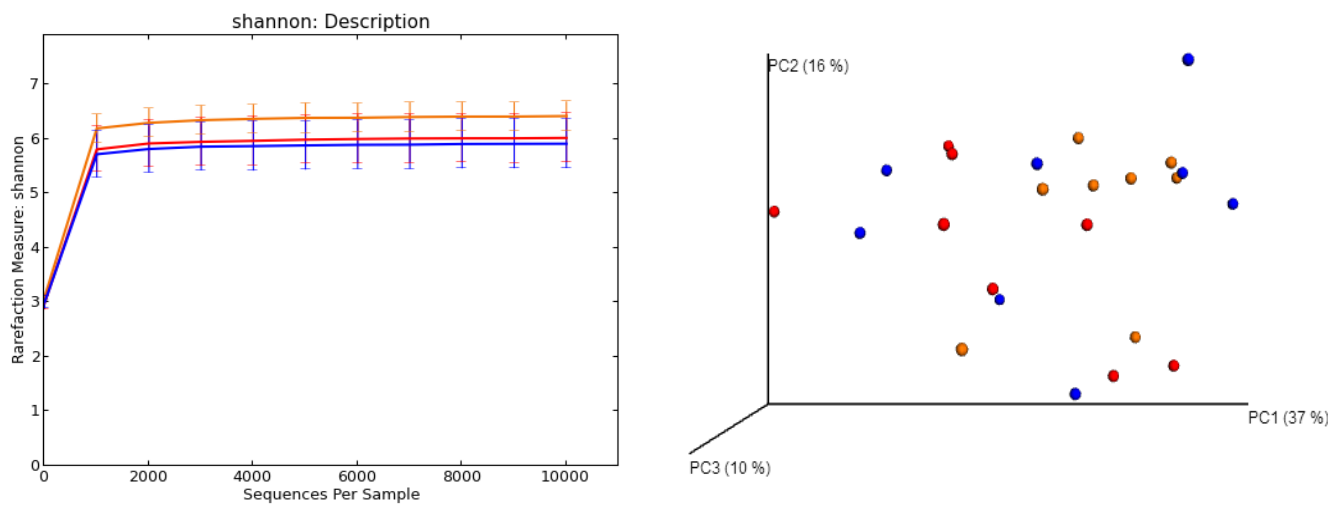

Colon

Figure 3. Cont. 

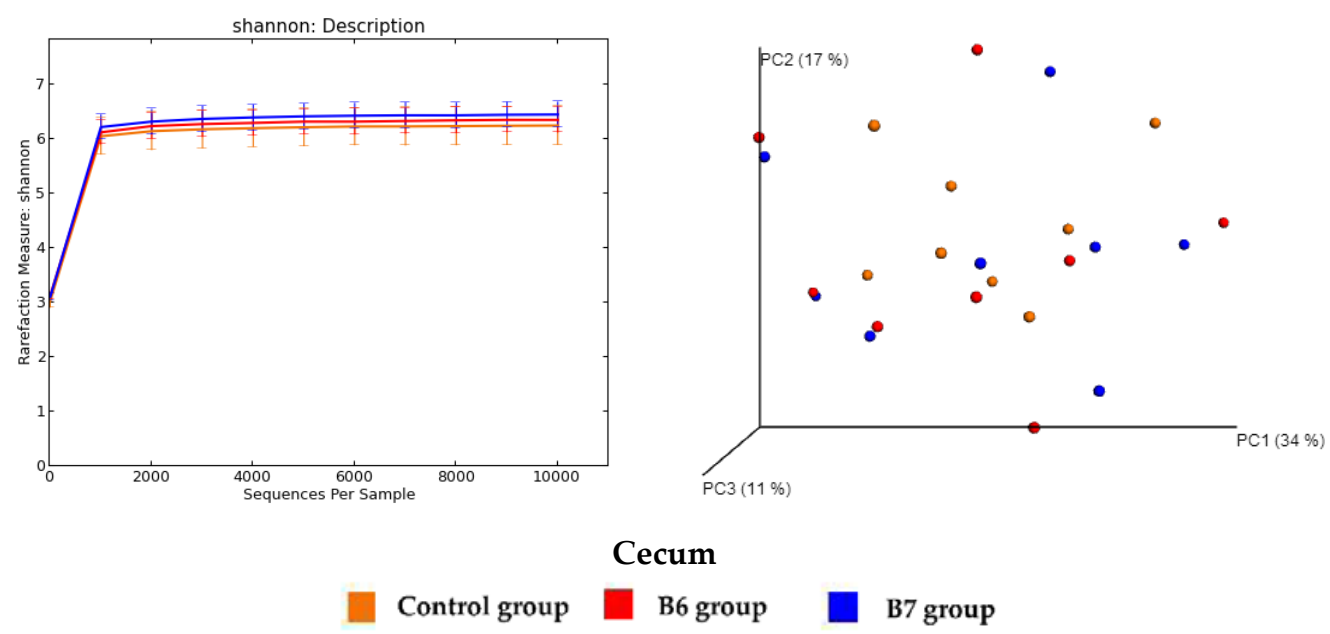

Figure 3. The Shannon $\alpha$-diversity index (rarefaction curves) and $\beta$-diversity (weighted UniFrac principal component analysis).

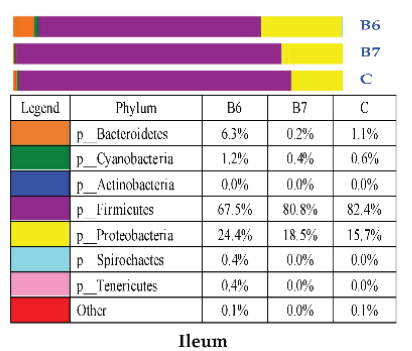

Ileum
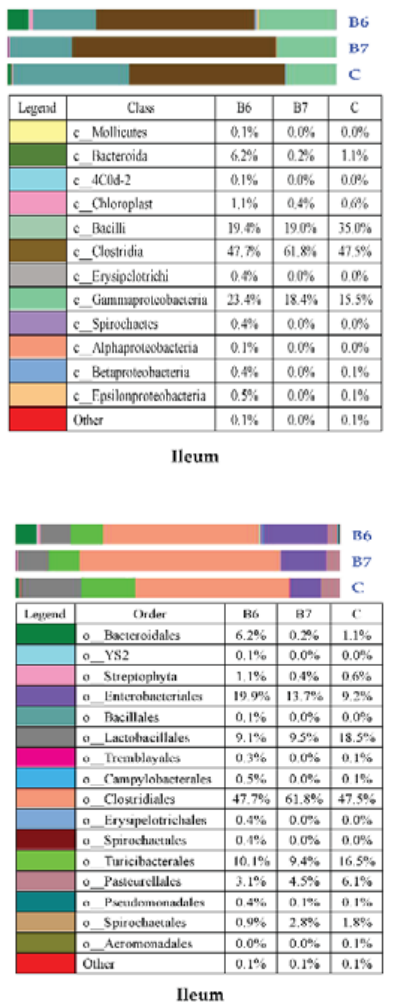

Ileum

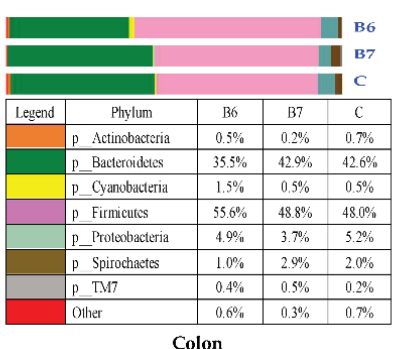

(a)

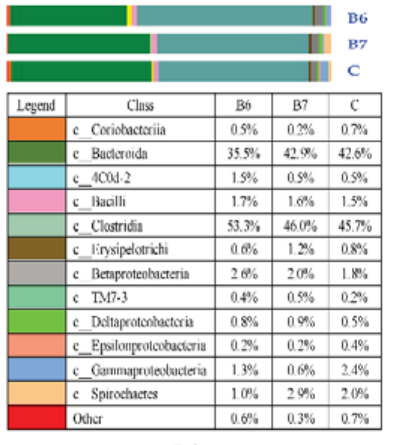

(b)

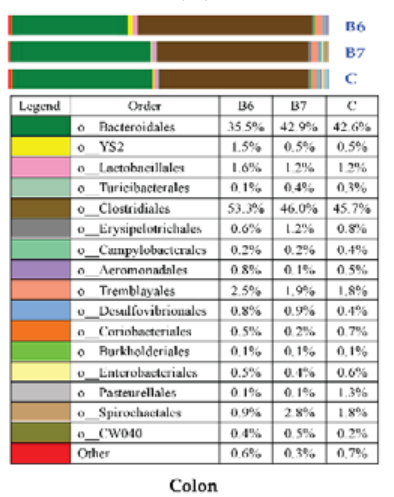

(c)
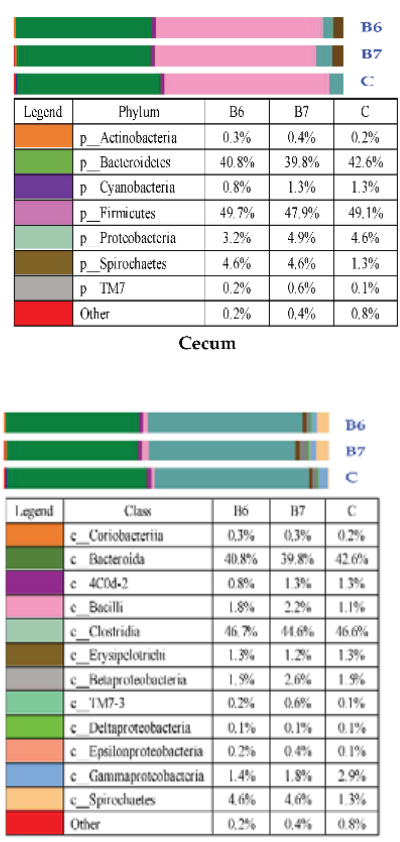

Cecum

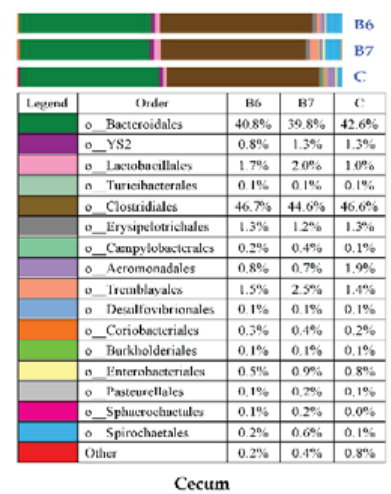

Cecum

Figure 4. Cont. 


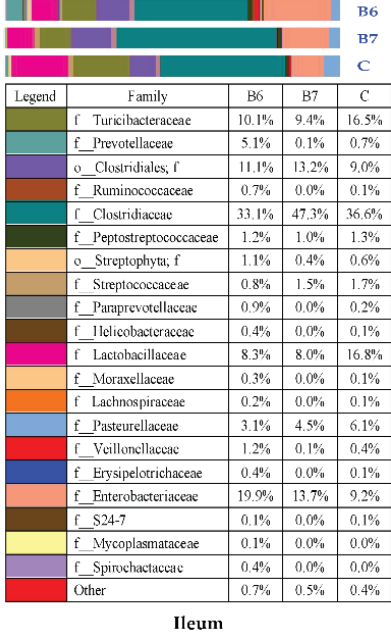
Ileum

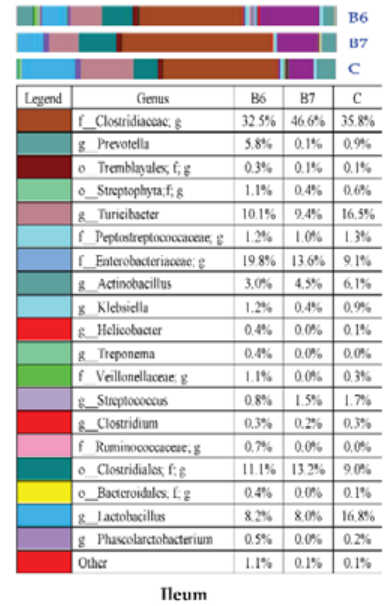

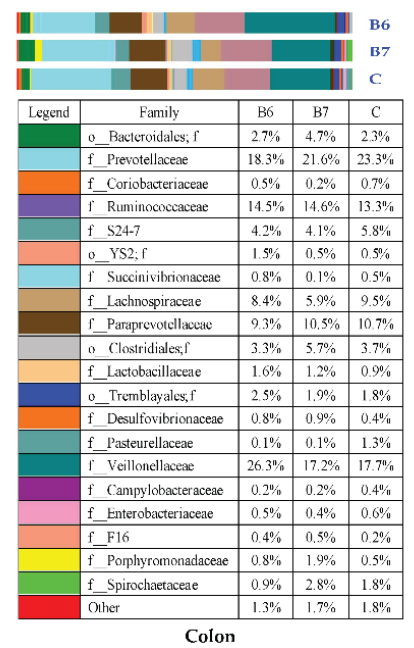

(d)

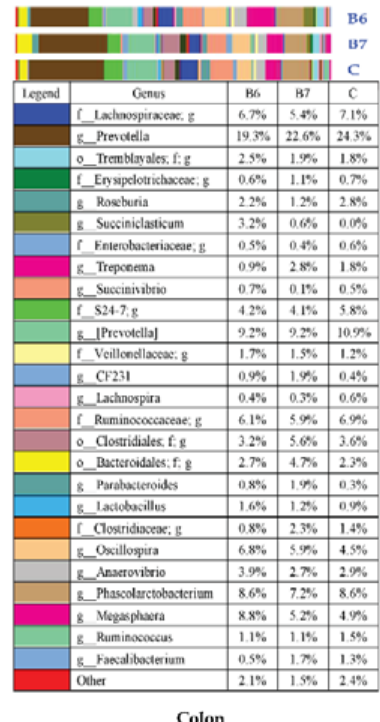

(e)
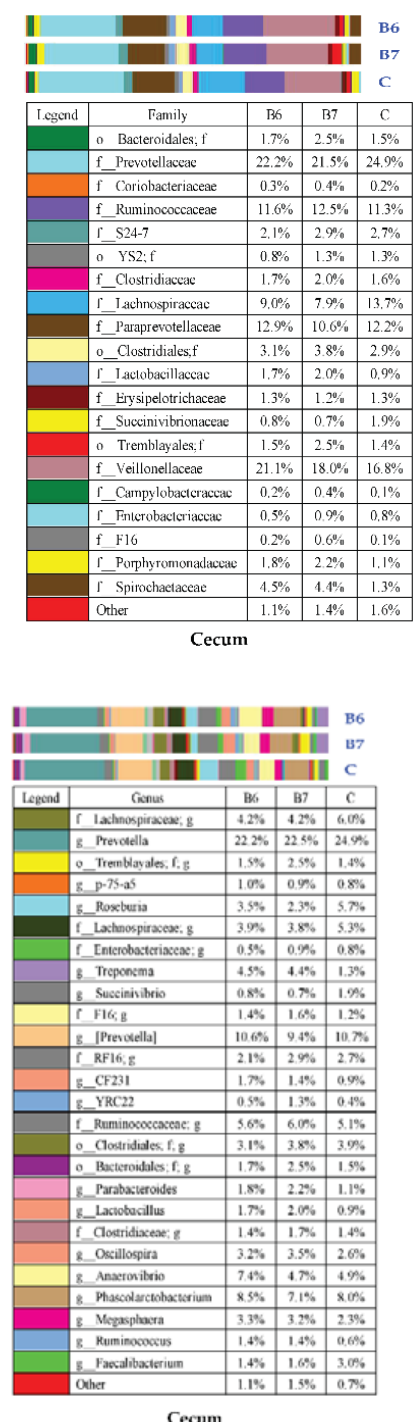

Cecum

Figure 4. (a) The community composition at the phylum level; (b) the community composition at the class level; (c) the community composition at the order level; (d) the community composition at the family level; and (e) the community composition at the genus level.

In the gut microbiota of mammals, Firmicutes and Bacteroidetes were the dominant phyla, followed by Fusobacteria, Proteobacteria, and Actinobacteria [54]. Previous studies have also presented the similar result that Firmicutes and Bacteroidetes were still the main phyla in pigs regardless of the growing ages or different intestinal segments [55]. Despite the variations showed in Figure 4a-e, only 36 OTUs underwent statistically significant changes among the groups (Table 6) and most of them belong to the genus, Prevotella, or are included in the order, Clostridiales, specifically in three of its families (Clostridiaceae, Lachnospiraceae, and Ruminocccaceae) and a very close one (Veillonellaceae). Prevotella tend to colonize animals and the human gut, and may cause infections, but can also co-exist harmlessly with their human host [56]. It is increasingly gaining attention as a commensal microbe in the intestine because of its ability to degrade a broad spectrum of plant polysaccharides [57]. The Veillonellaceae family are mainly bacteria related to the metabolism of nutrients, especially the metabolism of amino acids [58]. The Lachnospiraceae and Ruminococcaceae families are common gut microbes that break down complex carbohydrates, and they are most common in the digestive tracts of animals with carb-heavy diets. This is usually good for ruminants, which have a great difference to pigs $[59,60]$. 
In this study, the composition of some OTUs belonging to Prevotella, Veillonellaceae, Lachnospiraceae, and Ruminococcaceae had significant differences, indicating that supplementing B. coagulans could benefit and optimize the digestion and absorption of nutrients, thus, reducing anyt unnecessary waste of nutrients. The family, Clostridiaceae, belongs to the phylum, Firmicutes, and includes 40 genera. Members belonging to this family were isolated mainly from the environment and from commensal digestive microbiota of mammals. Many of them, particularly Clostridium, are the major pathogens of people and animals [61]. After supplementing B. coagulans, the composition of the genus, Clostridium, had a decrease in the colon, indicating that $B$. coagulans might have the capacity to inhibit the growth and reproduction of pathogenic microorganisms.

\section{Material and Methods}

\subsection{Experimental Design and Sample Collection}

The animal-use protocol for this research was approved by the Animal Care and Use Committee of the Hubei Province. The 24 healthy crossbred piglets (Duroc $\times$ Landrace $\times$ Yorkshire) were weaned at 21 day of age and fed with a corn and soybean meal-based diet. Each piglet was individually housed in a $1.20 \times 1.10 \mathrm{~m}^{2}$ steel metabolic cage. After a period of 3 days adaptation, piglets were assigned randomly on the basis of body weight and litter origin to 3 groups: (1) The control (C) group in which piglets were fed with the basal diet; (2) the B6 group in which piglets were fed with the basal diet supplemented with $2.0 \times 10^{6} \mathrm{CFU} / \mathrm{g}$ B. coagulans; and (3) the B7 group in which piglets were fed with the basal diet supplemented with $2.0 \times 10^{7} \mathrm{CFU} / \mathrm{g}$ B. coagulans. All diets were isocaloric [62]. On the $21^{\text {st }}$ day of the trial, blood, intestine, and digesta samples were collected and stored at $-80^{\circ} \mathrm{C}$ until assay according to a previous study [63].

B. coagulans were produced by fermenting; the conditions were $200 \mathrm{r} / \mathrm{min}$ of stirring speed and $350 \mathrm{~L} / \mathrm{h}$ of throughput. The products of fermentation were filtered by organic ceramic membrane filtration equipment, and mixed with mineral adsorbent by 1:1. Final products were a dry powder that were counted by the plate counting method to determine the dosage and then were mixed in the diet.

\subsection{Plasma Biochemical Indicators and Intestinal Redox Status}

Plasma biochemical indicators were measured with corresponding kits using a Hi-tachi 7060 Automatic Biochemical Analyzer (Hitachi, Tokyo, Japan), and the activities of DAO, SOD, and CAT, and the content of MDA and $\mathrm{H}_{2} \mathrm{O}_{2}$ were determined using commercially available kits (Jiancheng Bioengineering Institute, Nanjing, China). Assays were performed in triplicate.

\subsection{Intestinal Morphology}

To determine the intestinal morphology, paraformaldehyde-fixed jejunum and ileum samples were dehydrated and embedded in paraffin. 5- $\mu \mathrm{m}$ sections were cut and then stained with hematoxylin and eosin stain. Intestinal morphology was determined using a light microscope (Leica, Solms, Germany), with the Leica Application Suite image analysis software (Leica, Solms, Germany). The villus area was quantitated from the perimeter and height of the villi. The ratio of the villus height to crypt depth was calculated.

\subsection{Expression Levels of Proteins}

The expression levels of proteins were performed using western blotting as described by Hou et al. [64]. The primary antibodies: HSP70, Caspase-3, Bax, Villin, and Occludin (rabbit, 1:1000; Cell Signaling Technology, Inc., Danvers, MA, USA), $\beta$-actin (mouse 1:2000; Sigma-Aldrich Inc., St. Louis, MI, USA). The secondary antibody: Anti-rabbit (mouse, 1:2000; Zhongshan Golden Bridge Biological Technology Co., Ltd., Beijing, China). Blots were carried out by utilizing a chemiluminescence kit (Amersham Biosciences, Uppsala, Sweden) and image forming system (Alpha Innotech, New York, NY, USA). 


\subsection{Expression Levels of Genes}

The gene expression levels were quantitated by the method of real-time PCR as described by Yi et al. [65]. The real-time PCR was carried out with primers (Table 7) of these genes, as well as the reference gene, ribosomal protein L 4 (RPL4), and the SYBR ${ }^{\circledR}$ Premix Ex Taq ${ }^{\mathrm{TM}}$ (Takara, Dalian, China) on 7500 Fast Real-Time PCR System (Applied Biosystems, Foster City, CA, USA). Data was analyzed by the $2^{-\Delta \mathrm{Ct}}$ method as described by [65].

Table 7. Primers for real-time PCR analysis.

\begin{tabular}{ccc}
\hline Gene & Forward & Reverse \\
\hline$R P L 4$ & GAGAAACCGTCGCCGAAT & GCCCACCAGGAGCAAGTT \\
$I F N-\alpha$ & ACTCCATCCTGGCTGTGAGGAAAT & ATCTCATGACTTCTGCCCTGACGA \\
$I F N-\beta$ & ATGTCAGAAGCTCCTGGGACAGTT & AGGTCATCCATCTGCCCATCAAGT \\
$I F N-\gamma$ & TCTGGGAAACTGAATGACTTCG & GACTTCTCTTCCGCTTTCTTAGGTT \\
$M X 1$ & AGTGCGGCTGTTTACCAAG & TTCACAAACCCTGGCAACTC \\
$M X 2$ & CGCATTCTTTCACTCGCATC & CCTCAACCCACCAACTCACA \\
$O A S 1$ & TGGTGGTGGAGACACACACA & CCAACCAGAGACCCATCCA \\
$I L-1 \beta$ & CAACGTGCAGTCTATGGAGT & GAGGTGCTGATGTACCAGTTG \\
$I L-4$ & AGGAGCCACACGTGCTTGA & TTGCCAAGCTGTTGAGATTCC \\
$C X C L-9$ & CTTGCTTTTGGGTATCATCTTCCT & TCATCCTTTGGCTGGTGTTG \\
$C C L-2$ & CATAAGCCACCTGGACAAGAAAA & GGGTATTTAGGGCAAGTTAGAAGGA \\
$A Q P 3$ & AAGCTGTCCCAAGTAAAGCACAA & GCCCTACTTCCTGTTTCACCAC \\
$S G L T-1$ & CCCAAATCAGAGCATTCCATTCA & AAGTATGGTGTGGTGGCCGGTT \\
$L P L$ & AGCCTGAGTTGGACCCATGT & CTCTGTTTTCCCTTCCTCTCTCC \\
$I N S R$ & GGGGCTAAAGAGGAACTATGAGG & AGAGGAAAGCGAAGACAGGAAA \\
$b^{0,+} A T$ & CGAGTACCCGTACCTGATGGA & TGCGTAGAAGGGCGAAGAA \\
\hline
\end{tabular}

\subsection{Analysis of Gut Microbiota}

Total bacterial DNA was extracted, the gene-specific sequences targeted the $16 \mathrm{~S} \mathrm{~V} 3$ and V4 regions and were amplified with two stage PCR, and then were analyzed by MiSeq sequencing. The results were processed with QIIME as described by Caporaso et al. [66].

$\alpha$-Diversity metrics were calculated using a read depth of 10,000 and a $\beta$-diversity distance matrix was calculated based on thr UniFrac metric, which was used for the principal coordinates analysis [67]. The significance of the diet effect on the $\beta$-diversity distance matrix was assessed by PERMANOVA analysis [67]. Raw sequence data and detection and removal of chimeras were performed using the software, USEARCH and UCHIIME [66,68].

\subsection{Statistical Analysis}

Data were analyzed using a one-way analysis of variance to analysis, expressed as mean values \pm SEM. All experimental data was analysed using SPSS (Version 17.0, SPSS Inc., Chicago, IL, USA). A $p$-value of $<0.05$ was considered statistically significant. The data of the gut microbiota were processed by QIIME platform.

\section{Conclusions}

Supplementing B. coagulans in the small intestine of weaning piglets had beneficial impacts on improving the growth performance, lowering the diarrhea rate, promoting nutrients' metabolism, maintaining intestinal integrity, and alleviating oxidative stress. Further research of molecular mechanisms showed that these beneficial impacts might be regulated by changing expression levels of related proteins and genes and altering the community composition of the gut microbiota.

Author Contributions: T.W. and Y.H. conceived and designed the experiments; Y.Z., L.P., and Y.L. performed the experiments; D.Z., L.W., and D.Y. analyzed the data; H.C., J.G., and Y.H. contributed analysis tools and helped in the Results and Discussion Section; Y.L. wrote this paper. All authors read and approved the manuscript. 
Funding: This work was supported by National Key Research and Development Program of China (2017YFD0500505) and Hubei Provincial Technology and Innovation Program (2017AHB062).

Conflicts of Interest: The authors declare that no conflict of interest.

\section{References}

1. Pluske, J.R.; Hampson, D.J.; Williams, I.H. Factors influencing the structure and function of the small intestine in the weaned pig: A review. Livest. Prod. Sci. 1997, 51, 215-236. [CrossRef]

2. De, G.A.; Resink, J.W.; VanHees, H.M.; Ruuls, L.; Klaassen, G.J.; Rouwers, S.M.; Stockhofe-Zurwieden, N. Supplementation of piglets with nutrient-dense complex milk replacer improves intestinal development and microbial fermentation. J. Anim. Sci. 2016, 94, 1012-1019.

3. Moeser, A.J.; Pohl, C.S.; Rajput, M. Weaning stress and gastrointestinal barrier development: Implications for lifelong gut health in pig. Anim. Nutr. 2017, 3, 313-321. [CrossRef] [PubMed]

4. Montagne, L.; Boudry, G.; Favier, C.; Le Huërou-Luron, I.; Lallès, J.P.; Sève, B. Main intestinal markers associated with the changes in gut architecture and function in piglets after weaning. Br. J. Nutr. 2007, 97, 45-57. [CrossRef] [PubMed]

5. Moeser, A.J.; Ryan, K.A.; Nighot, P.K.; Blikslager, A.T. Gastrointestinal dysfunction induced by early weaning is attenuated by delayed weaning and mast cell blockade in pigs. Am. J. Physiol. Gastrointest. Liver Physiol. 2007, 293, G413-G421. [CrossRef] [PubMed]

6. Etheridge, R.D.; Seerley, R.W.; Wyatt, R.D. The effect of diet on performance, digestibility, blood composition and intestinal microflora of weaned pigs. J. Anim. Sci. 1984, 58, 1396-1402. [CrossRef] [PubMed]

7. Hamard, A.; Sève, B.; Le, F.N. Intestinal development and growth performance of early-weaned piglets fed a low-threonine diet. Animal 2007, 1, 1134-1142. [CrossRef] [PubMed]

8. Bergen, W.G.; Wu, G. Intestinal nitrogen recycling and utilization in health and disease. J. Nutr. 2009, 139, 821-825. [CrossRef] [PubMed]

9. Dai, Z.L.; Li, X.L.; Xi, P.B.; Zhang, J.; Wu, G.; Zhu, W.Y. L-Glutamine regulates amino acid utilization by intestinal bacteria. Amino Acids 2013, 45, 501-512. [CrossRef] [PubMed]

10. Brosnan, J.T.; Brosnan, M.E. Glutamate: A truly functional amino acid. Amino Acids 2013, 45, 413-418. [CrossRef] [PubMed]

11. Liu, Y.L.; Huang, J.J.; Hou, Y.Q.; Zhu, H.L.; Zhao, S.J.; Ding, B.Y.; Yin, Y.L.; Yi, G.F.; Shi, J.Y.; Fan, W. Dietary arginine supplementation alleviates intestinal mucosal disruption induced by Escherichia coli lipopolysaccharide in weaned pigs. Br. J. Nutr. 2008, 100, 552-560. [CrossRef] [PubMed]

12. Dai, Z.L.; Wu, G.; Zhu, W.Y. Amino acid metabolism in intestinal bacteria: Links between gut ecology and host health. Front. Biosci. 2011, 16, 1768-1786. [CrossRef]

13. Xin, W.; Zheng, R.; Kong, X.F.; Tang, Z.R.; Dong, X.H. Functions of microbiota in monogastric gastrointestinal tract and new practices in animal production. J. Food Agric. Environ. 2010, 8, 695-702.

14. Arunachalam, K.D. Role of Bifidobacteria in nutrition, medicine and technology. Nutr. Res. 1999, 19, 1559-1597. [CrossRef]

15. Bon, M.L.; Davies, H.E.; Glynn, C.; Thompson, C.; Madden, M.; Wiseman, J.; Dodd, C.; Hurdidge, L.; Payne, G.; Treut, Y.L.; et al. Influence of probiotics on gut health in the weaned pig. Livest. Sci. 2010, 133, 179-181. [CrossRef]

16. Xuan, Z.N.; Kim, J.D.; Heo, K.N.; Jung, H.J.; Lee, J.H.; Han, Y.K.; Kim, Y.Y.; Han, I.K. Study on the development of a probiotics complex for weaned pigs. Asian Aust. J. Anim. Sci. 2001, 14, 1425-1428. [CrossRef]

17. Wang, J.Q.; Yin, F.G.; Zhu, C.; Yu, H.; Niven, S.J.; DeLange, C.F.M.; Gong, J. Evaluation of probiotic bacteria for their effects on the growth performance and intestinal microbiota of newly-weaned pigs fed fermented high-moisture maize. Livest. Sci. 2012, 145, 79-86. [CrossRef]

18. Payot, T.; Chemaly, Z.; Fick, M. Lactic acid production by Bacillus coagulans-Kinetic studies and optimization of culture medium for batch and continuous fermentations. Enzyme Microb. Technol. 1999, 24, 191-199. [CrossRef]

19. Zhou, X.; Wang, Y.; Gu, Q.; Li, W. Effect of dietary probiotic, Bacillus coagulans, on growth performance, chemical composition, and meat quality of Guangxi Yellow chicken. Poul. Sci. 2010, 89, 588-593. [CrossRef] [PubMed] 
20. Hung, A.T.; Lin, S.Y.; Yang, T.Y.; Chou, C.K.; Liu, H.C.; Lu, J.J.; Wang, B.; Chen, S.Y.; Lien, T.F. Effects of Bacillus coagulans ATCC 7050 on growth performance, intestinal morphology, and microflora composition in broiler chickens. Anim. Prod. Sci. 2012, 52, 874-879. [CrossRef]

21. Ripamonti, B.; Agazzi, A.; Baldi, A.; Balzaretti, C.; Bersani, C.; Pirani, S.; Rebucci, R.; Savoini, G.; Stella, S.; Stenico, A.; et al. Administration of Bacillus coagulans, in calves: Recovery from faecal samples and evaluation of functional aspects of spores. Vet. Res. Commun. 2009, 33, 991-1001. [CrossRef] [PubMed]

22. Hyronimus, B.; Marrec, C.L.; Urdaci, M.C. Coagulin, a bacteriocin-like inhibitory substance produced by Bacillus coagulans I4. J. Appl. Microbiol. 1998, 85, 42-50. [CrossRef] [PubMed]

23. Baron, M. A patented strain of Bacillus coagulans increased immune response to viral challenge. Postgrad. Med. 2009, 121, 114-118. [CrossRef] [PubMed]

24. Kristal-Boneh, E.; Harari, G.; Green, M.S. Circannual Variations in Blood Cholesterol Levels. Chronobiol. Int. 1993, 10, 37-42. [CrossRef] [PubMed]

25. Bae, Y.J.; Choi, M.K.; Kim, M.H. Manganese supplementation reduces the blood cholesterol levels in Ca-deficient ovariectomized rats. Biol. Trace Elem. Res. 2011, 141, 224-231. [CrossRef] [PubMed]

26. Stole, E.; Smith, T.K.; Manning, J.M.; Meister, A. Interaction of gamma-glutamyl transpeptidase with acivicin. J. Biol. Chem. 1994, 269, 21435-21439. [PubMed]

27. Braun, J.P.; Benard, P.; Burgat, V.; Rico, A.G. Gamma Glutamyl Transferase in domestic animals. Vet. Res. Commun. 1983, 6, 77-90. [CrossRef] [PubMed]

28. Agúndez, J.A.; Ayuso, P.; Cornejo-García, J.A.; Blanca, M.; Torres, M.J.; Doña, I.; Salas, M.; Blanca-López, N.; Canto, G.; Rondon, C.; et al. The diamine oxidase gene is associated with hypersensitivity response to non-steroidal anti-inflammatory drugs. PLOS ONE 2012, 7, e47571. [CrossRef] [PubMed]

29. Kitanaka, J.; Kitanaka, N.; Tsujimura, T.; Terada, N.; Takemura, M. Expression of diamine oxidase (histaminase) in guinea-pig tissues. Eur. J. Pharmacol. 2002, 437, 179-185. [CrossRef]

30. Pluske, J.R.; Williams, I.H.; Aherne, F.X. Maintenance of villous height and crypt depth in piglets by providing continuous nutrition after weaning. Anim. Sci. 1996, 62, 131-144. [CrossRef]

31. Cera, K.R.; Mahan, D.C.; Cross, R.F.; Reinhart, G.A.; Whitmoyer, R.E. Effect of age, weaning and postweaning diet on small intestinal growth and jejunal morphology in young swine. J. Anim. Sci. 1988, 66, 574-584. [CrossRef] [PubMed]

32. Cabello-Verrugio, C.; Ruiz-Ortega, M.; Mosqueira, M.; Simon, F. Oxidative Stress in Disease and Aging: Mechanisms and Therapies. Oxid. Med. Cell. Longev. 2016, 2016. [CrossRef] [PubMed]

33. Yu, B.P. Cellular defenses against damage from reactive oxygen species. Physiol. Rev. 1994, 74, $139-162$. [CrossRef] [PubMed]

34. Harris, E.D. Regulation of antioxidant enzymes. J. Nutr. 1992, 122, 625-626. [CrossRef] [PubMed]

35. Del Rio, D.; Stewart, A.J.; Pellegrini, N. A review of recent studies on malondialdehyde as toxic molecule and biological marker of oxidative stress. Nutr. Metab. Cardiovasc. Dis. 2005, 15, 316-328. [CrossRef] [PubMed]

36. Sies, H. Role of metabolic $\mathrm{H}_{2} \mathrm{O}_{2}$ generation: Redox signaling and oxidative stress. J. Biol. Chem. 2014, 289, 8735-8741. [CrossRef] [PubMed]

37. Buchmeier, N.A.; Heffron, F. Induction of Salmonella stress proteins upon infection of macrophages. Science 1990, 248, 730-732. [CrossRef] [PubMed]

38. Snigdha, S.; Smith, E.D.; Prieto, G.A.; Cotman, C.W. Caspase-3 activation as a bifurcation point between plasticity and cell death. Neurosci. Bull. 2012, 28, 14-24. [CrossRef] [PubMed]

39. Kirkland, R.A.; Saavedra, G.M.; Cummings, B.S.; Franklin, J.L. Bax regulates production of superoxide in both apoptotic and nonapoptotic neurons: Role of caspases. J. Neurosci. 2010, 30, 16114-16127. [CrossRef] [PubMed]

40. Friederich, E.; Pringault, E.; Arpin, M.; Louvard, D. From the structure to the function of villin, an actin-binding protein of the brush border. Bioessays 1990, 12, 403-408. [CrossRef] [PubMed]

41. Schneeberger, E.E.; Lynch, R.D. The tight junction: A multifunctional complex. Am. J. Physiol. Cell Physiol. 2004, 286, C1213-C1228. [CrossRef] [PubMed]

42. Theofilopoulos, A.N.; Baccala, R.; Beutler, B.; Kono, D.H. Type I interferons $(\alpha / \beta)$ in immunity and autoimmunity. Annu. Rev. Immunol. 2005, 23, 307-336. [CrossRef] [PubMed]

43. Takaoka, A.; Yanai, H. Interferon signalling network in innate defence. Cell. Microbiol. 2006, 8, 907-922. [CrossRef] [PubMed] 
44. García-Sastre, A.; Biron, C.A. Type 1 interferons and the virus-host relationship: A lesson in Détente. Science 2006, 312, 879-882. [CrossRef] [PubMed]

45. Matsumiya, T.; Hayakari, R.; Narita, N.; Ito, R.; Kon, T.; Kubota, K.; Sakaki, H.; Yoshida, H.; Imaizumi, T.; Kobayashi, W.; et al. Role of type I- and type II-interferon in expression of melanoma differentiation-associated gene-5 in HSC-3 oral squamous carcinoma cells. Biomed. Res. 2014, 35, 9-16. [CrossRef] [PubMed]

46. Franco, J.G.; Lisboa, P.C.; Lima, N.S.; Amaral, T.A.; Peixoto-Silva, N.; Resende, A.C.; Oliveira, E.; Passos, M.C.; Moura, E.G. Resveratrol attenuates oxidative stress and prevents steatosis and hypertension in obese rats programmed by early weaning. J. Nutr. Biochem. 2013, 24, 960-966. [CrossRef] [PubMed]

47. Villehuchet, A.M.; Brack, M.; Dreyfus, G.; Oussar, Y.; Bonnefont-Rousselot, D.; Chapman, M.J.; Kontush, A. A machine-learning approach to the prediction of oxidative stress in chronic inflammatory disease. Redox. Rep. 2009, 14, 23-33. [CrossRef] [PubMed]

48. Wei, Y.H.; Lu, C.Y.; Wei, C.Y.; Ma, Y.S.; Lee, H.C. Oxidative stress in human aging and mitochondrial disease-consequences of defective mitochondrial respiration and impaired antioxidant enzyme system. Chin. J. Physiol. 2001, 44, 1-12. [PubMed]

49. Jiang, X.C.; Moulin, P.; Quinet, E.; Goldberg, I.J.; Yacoub, L.K.; Agellon, L.B.; Compton, D.; Schnitzer-Polokoff, R.; Tall, A.R. Mammalian adipose tissue and muscle are major sources of lipid transfer protein mRNA. J. Biol. Chem. 1991, 266, 4631-4639. [PubMed]

50. Sarfstein, R.; Werner, H. Insulin receptor (INSR) and insulin-like growth factor-I receptor (IGF-GR) translocate to nucleus and regulate IGF-GR gene expression in breast cancer cells. Growth Horm. IGF Res. 2012, 22, S4. [CrossRef]

51. Arnspang, E.C.; Sundbye, S.; Nelson, W.J.; Nejsum, L.N. Aquaporin-3 and aquaporin-4 are sorted differently and separately in the trans-Golgi network. PLoS ONE 2013, 8, e73977. [CrossRef] [PubMed]

52. Tavakkolizadeh, A.; Berger, U.V.; Shen, K.R.; Levitsky, L.L.; Zinner, M.J.; Hediger, M.A.; Ashley, S.W.; Whang, E.E.; Rhoads, D.B. Diurnal rhythmicity in intestinal SGLT-1 function, V(max), and mRNA expression topography. Am. J. Physiol. Gastrointest. Liver Physiol. 2001, 280, G209-G215. [CrossRef] [PubMed]

53. Romeo, E.; Dave, M.H.; Bacic, D.; Ristic, Z.; Camargo, S.M.; Loffing, J.; Wagner, C.A.; Verrey, F. Luminal kidney and intestine SLC6 amino acid transporters of B0AT-cluster and their tissue distribution in Mus musculus. Am. J. Physiol. Ren. Physiol. 2006, 290, F376-F383. [CrossRef] [PubMed]

54. Pedersen, R.; Andersen, A.D.; Molbak, L.; Stagsted, J.; Boye, M. Changes in the gut microbiota of cloned and non-cloned control pigs during development of obesity: Gut microbiota during development of obesity in cloned pigs. BMC Microbiol. 2013, 13, 30. [CrossRef] [PubMed]

55. Ramadan, Z.; Xu, H.; Laflamme, D.; Czarnecki-Maulden, G.; Li, Q.J.; Labuda, J.; Bourqui, B. Fecal Microbiota of Cats with Naturally Occurring Chronic Diarrhea Assessed Using 16S rRNAGene 454-Pyrosequencing before and after Dietary Treatment. J. Vet. Int. Med. 2014, 28, 59-65. [CrossRef]

56. Kang, D.W.; Park, J.G.; Ilhan, Z.E.; Wallstrom, G.; LaBaer, J.; Adams, J.B.; Krajmalnik-Brown, R. Reduced incidence of Prevotella and other fermenters in intestinal microflora of autistic children. PLoS ONE 2013, 8 , e68322. [CrossRef] [PubMed]

57. Wu, G.D.; Chen, J.; Hoffmann, C.; Bittinger, K.; Chen, Y.Y.; Keilbaugh, S.A.; Bewtra, M.; Knights, D.; Walters, W.A.; Knight, R.; et al. Linking longterm dietary patterns with gut microbial enterotypes. Science 2011, 333, 105-108. [CrossRef] [PubMed]

58. Sabine, G.; Sabine, W.; Alla, L.; Goegelel, H.; Sifri, C.D.; Martin, K.; Hinder, R.; Nguyen, J.H. Complete genome sequence of Veillonella parvula type strain (Te3). Stand. Genom. Sci. 2010, 2, 57-65.

59. Biddle, A.; Stewart, L.; Blanchard, J.; Leschine, S. Untangling the Genetic Basis of Fibrolytic Specialization by Lachnospiraceae and Ruminococcaceae in Diverse Gut Communities. Diversity 2013, 5, 627-640. [CrossRef]

60. Shang, Q.; Shan, X.; Cai, C.; Hao, J.; Li, G.; Yu, G. Dietary fucoidan modulates the gut microbiota in mice by increasing the abundance of Lactobacillus and Ruminococcaceae. Food Funct. 2016, 7, 3224-3232. [CrossRef] [PubMed]

61. Skerman, V.B.D.; McGowan, V.; Sneath, P.H.A. Approved lists of bacterial names. Int. J. Syst. Bacteriol. 1980, 30, 225-420. [CrossRef]

62. Hou, Y.Q.; Wang, L.; Ding, B.Y. Dietary $\alpha$-ketoglutarate supplementation ameliorates intestinal injury in lipopolysaccharidechallenged piglets. Amino Acids 2010, 39, 555-564. [CrossRef] [PubMed] 
63. Yasuda, K.; Dawson, H.D.; Wasmuth, E.V.; Roneker, C.A.; Chen, C.; Urban, J.F.; Welch, R.M.; Miller, D.D.; Lei, X.G. Supplemental dietary inulin influences expression of iron and inflammation related genes in young pigs. J. Nutr. 2009, 139, 2018-2023. [CrossRef] [PubMed]

64. Hou, Y.; Yao, K.; Wang, L.; Ding, B.; Fu, D.; Liu, Y.; Zhu, H.; Liu, J.; Li, Y.; Kang, P.; et al. Effects of $\alpha$-ketoglutarate on energy status in the intestinal mucosa of weaned piglets chronically challenged with lipopolysaccharide. Br. J. Nutr. 2011, 106, 357-363. [CrossRef] [PubMed]

65. Yi, D.; Hou, Y.; Wang, L.; Zhao, D.; Ding, B.; Wu, T.; Chen, H.; Liu, Y.; Kang, P.; Wu, G. Gene expression profiles in the intestine of lipopolysaccharide-challenged piglets. Front. Biosci. 2016, 21, 487-501.

66. Caporaso, J.G.; Kuczynski, J.; Stombaugh, J.; Bittinger, K.; Bushman, F.D.; Costello, E.K.; Fierer, N.; Peña, A.G.; Goodrich, J.K.; Gordon, J.I.; et al. QIIME allows analysis of high-throughput community sequencing data. Nat. Methods 2010, 7, 335-336. [CrossRef] [PubMed]

67. Lozupone, C.; Knight, R. UniFrac: A new phylogenetic method for comparing microbial communities. Appl. Environ. Microbiol. 2005, 71, 8228-8235. [CrossRef] [PubMed]

68. Price, M.N.; Dehal, P.S.; Arkin, A.P. FastTree: Computing large minimum evolution trees with profiles instead of a distance matrix. Mol. Biol. Evol. 2009, 26, 1641-1650. [CrossRef] [PubMed]

(C) 2018 by the authors. Licensee MDPI, Basel, Switzerland. This article is an open access article distributed under the terms and conditions of the Creative Commons Attribution (CC BY) license (http://creativecommons.org/licenses/by/4.0/). 